\title{
Cytotoxic and mutagenic effects of iodine-131 and radioprotection of acerola (Malpighia glabra L.) and beta-carotene in vitro
}

I.V. Almeida ${ }^{1}$, E. Düsman ${ }^{1}$, M.C. Heck ${ }^{1}$, J.A. Pamphile ${ }^{1}$, N.B. Lopes ${ }^{2}$, L.T.D. Tonin ${ }^{3}$ and V.E.P. Vicentini ${ }^{1}$

${ }^{1}$ Laboratório de Citogenética e Mutagênese, Departamento de Biotecnologia, Genética e Biologia Celular, Universidade Estadual de Maringá, Maringá, PR, Brasil

${ }^{2}$ Departamento de Física, Universidade Estadual de Maringá, Maringá, PR, Brasil

${ }^{3}$ Universidade Tecnológica Federal do Paraná, Campus Apucarana, Apucarana, PR, Brasil

Corresponding author: E. Düsman

E-mail: lisdusman@yahoo.com.br

Genet. Mol. Res. 12 (4): 6402-6413 (2013)

Received September 11, 2013

Accepted November 5, 2013

Published December 10, 2013

DOI http://dx.doi.org/10.4238/2013.December.10.1

\begin{abstract}
The radioisotope iodine-131 $\left[{ }^{131} \mathrm{I}\right]$ can damage DNA. One way to prevent this is to increase the amount of antioxidants via dietary consumption. The goal of this study was to evaluate the radioprotective effect of fresh acerola pulp and synthetic beta-carotene in Rattus norvegicus hepatoma cells (HTC) in response to $\left.{ }^{131} \mathrm{I}\right]$ exposure in vitro. Cellular DNA damage was subsequently assessed using a cytokinesis block micronucleus assay. The mutagenic and cytotoxic activities of doses of $\left[{ }^{131} \mathrm{I}\right](0.1,0.5,1,5$, and $10 \mu \mathrm{Ci})$, acerola $(0.025,0.125$, and $0.25 \mathrm{~g}$ acerola pulp $/ \mathrm{mL})$, and beta-carotene $(0.2$, 1 , and $2 \mu \mathrm{M})$ were evaluated. Radioprotective tests were performed
\end{abstract}


by simultaneous treatment with acerola $(0.25 \mathrm{~g} / \mathrm{mL})$ plus $\left[{ }^{131} \mathrm{I}\right](10$ $\mu \mathrm{Ci})$ and beta-carotene $(0.2 \mu \mathrm{M})$ plus $\left[{ }^{131} \mathrm{I}\right](10 \mu \mathrm{Ci})$. Acerola, betacarotene, and low concentrations of $\left[{ }^{131} \mathrm{I}\right]$ did not induce micronucleus formation in HTC cells; in contrast, high concentrations of $\left[{ }^{131} \mathrm{I}\right]$ (10 $\mu \mathrm{Ci}$ ) were mutagenic and induced DNA damage. Moreover, neither acerola nor beta-carotene treatment was cytotoxic. However, acerola reduced the percentage of $\left[{ }^{131} \mathrm{I}\right]$-induced damage, although betacarotene did not show a similar effect. Thus, our results suggest that acerola diet supplementation may benefit patients who are exposed to $\left[{ }^{131} \mathrm{I}\right]$ during thyroid diagnostics and therapy.

Key words: Antioxidants; Antimutagenic; Cell culture; Ionizing radiation; Radiotherapy

\section{INTRODUCTION}

It is well known that exposure to certain environmental substances can cause genetic mutations. Because mutations are often associated with the development of cancer and teratogenesis, information regarding the mutagenic potential of various agents, especially those used in medicine, is crucial (Loureiro et al., 2002).

Nuclear medicine uses radioisotopes to diagnose and treat various diseases. The radioisotope iodine-131 $\left[{ }^{131} \mathrm{I}\right]$ is currently used to diagnose thyroid dysfunction and to treat hyperthyroidism and differentiated thyroid cancer (Thrall and Ziessman, 2003). This isotope emits beta particles $(\beta)(E=0.61 \mathrm{MeV})$ and gamma rays $(\gamma)(E=0.36 \mathrm{MeV})$ and has a half-life of eight days (Turgut et al., 2006).

$\left[{ }^{131} \mathrm{I}\right]$ interacts with the surrounding environment and causes the formation of oxidizing free radicals via water radiolysis; free radicals may then react with intracellular macromolecules and alter cellular metabolism. Ionizing radiation also acts directly on nuclear DNA and may result in single- or double-strand breaks (Calegaro, 2007). Previous studies assessed the impact of various doses of radioiodine in several systems and indicated that isotope exposure increases the frequency of chromosomal aberrations (Puerto et al., 2000; da Silva et al., 2008; Düsman et al., 2011) and micronuclei (MN) (Watanabe et al., 2004; Joseph et al., 2009).

One way to prevent DNA damage and potential disease development is to avoid exposure to mutagenic agents. Alternatively, the administration of chemoprotective agents may increase resistance to mutagens/carcinogens and/or inhibit disease progression (De Flora and Fergurson, 2005).

Antioxidants are substances that can bind free radicals and significantly reduce or prevent oxidation of the substrate (Hosseinimehr, 2007). Specifically, antioxidants protect against free radical damage by preventing free radicals from attacking lipids, protein amino acids, and the double bond of polyunsaturated fatty acids and DNA bases, thereby preventing cellular damage (Ratnam et al., 2006). Free radicals can be generated by a number of sources, such as cellular metabolism or radioisotopes like $\left[{ }^{131} \mathrm{I}\right]$.

Antioxidant compounds can be obtained by the consumption of fruits and vegetables. Acerola (Malpighia glabra L.), from the family Malpighiaceae, is a native fruit of Central America that has high concentrations of the antioxidant vitamin $\mathrm{C}$, a high amount of vitamins 
A, B1, and B2, as well as carotenoids, anthocyanins, proteins, fats, carbohydrates, and minerals (Mezadri et al., 2006; Marques et al., 2007). One of the most potent antioxidant carotenoids is beta-carotene, which is a natural pigment present in numerous fruits and vegetables (BenAmotz et al., 1998).

The goal of this study was to evaluate the cytotoxic and mutagenic effects of $\left[{ }^{131} \mathrm{I}\right]$ and the radioprotective effect of fresh acerola fruit pulp and synthetic beta-carotene in Rattus norvegicus hepatoma cells (HTC) in vitro.

\section{MATERIAL AND METHODS}

\section{Cell line - HTC}

HTC cells derived from a $R$. norvegicus hepatoma were provided by Dr. Mario Sergio Mantovani (Universidade Estadual de Londrina, PR, Brazil). The cells were grown at $37^{\circ} \mathrm{C}$ in $25-\mathrm{cm}^{2}$ culture flasks containing $5 \mathrm{~mL}$ DMEM (Gibco) supplemented with $10 \%$ fetal bovine serum (Gibco). Under these conditions, the cell cycle time was approximately $24 \mathrm{~h}$.

\section{Evaluated substances}

Fresh acerola was prepared at the Medicinal Garden "Irenice Silva" at the State University of Maringá. Fifty grams of macerated fruit pulp was diluted in $10 \mathrm{~mL}$ phosphatebuffered saline (PBS) to facilitate filtration on filter paper and a $0.22-\mu \mathrm{m}$ cellulose acetate filter (Sartorius), and the concentrations $0.025,0.125$, and $0.25 \mathrm{~g} / \mathrm{mL}$ culture medium (DMEM supplemented with $10 \%$ fetal bovine serum). Beta-carotene (Sigma) was dissolved in dimethylsulfoxide (DMSO, Merck) and added at a final concentration of $0.2,1$, and $2 \mu \mathrm{M}$ beta-carotene per milliliter of cell growth medium. $\left[{ }^{131} \mathrm{I}\right]$ was obtained from the Institute of Nuclear and Energy Research (IPEN, São Paulo, Brazil). The isotope was diluted to a final concentration of $0.1,0.5,1,5$, and $10 \mu \mathrm{Ci}$ per $5 \mathrm{~mL}$ culture medium. For the negative control, $20 \mu \mathrm{L}$ PBS was added per milliliter of culture medium. A treatment with DMSO was performed at final a concentration of $10 \mu \mathrm{L} / \mathrm{mL}$ culture medium. The positive control was doxorubicin (DXR, Sigma) at a final concentration of $0.2 \mu \mathrm{g} / \mathrm{mL}$ culture medium, which in previous studies (Almeida et al., 2011) was shown to be optimal for the induction of DNA damage and showed responsiveness in the cell line used.

\section{Cytokinesis block micronucleus assay (MNCtB)}

Cells were incubated for $24 \mathrm{~h}$ with the various compounds to evaluate their mutagenicity and radioprotection. Radioprotective tests were performed by simultaneous treatment with acerola $(0.25 \mathrm{~g} / \mathrm{mL})$ plus $\left[{ }^{131} \mathrm{I}\right](10 \mu \mathrm{Ci})$ and beta-carotene $(0.2 \mu \mathrm{M})$ plus $\left[{ }^{131} \mathrm{I}\right](10 \mu \mathrm{Ci})$. Cell cultures were incubated with cytochalasin B (Sigma, $3 \mu \mathrm{g} / \mathrm{mL}$ culture medium) to obtain binucleated cells. The cells were harvested according to a previously published protocol by Martins de Oliveira et al. (2002). Briefly, the cells were trypsinized [500 $\mu \mathrm{L}$ trypsin- $0.025 \%$ EDTA (Gibco) at $37^{\circ} \mathrm{C}$, centrifuged $(5 \mathrm{~min}$ at $1000 \mathrm{rpm})$, hypotonized $(1.5 \mathrm{~mL} 1 \%$ sodium citrate), and fixed (5 mL 3:1 mixture of methanol:acetic acid). Doxorubicin (Sigma) was incubated with the cells for $24 \mathrm{~h}$ to serve as a positive control for DNA damage. 
All of the experiments were performed in triplicate; 3000 binucleated cells were analyzed per treatment to assess the frequency of micronuclei (MN), and 1500 cells were counted to determine the nuclear division index (NDI). The process for selecting binucleated cells, identifying micronuclei, and calculating the NDI was followed as described by Fenech (2000). The percentage reduction of damage was calculated using the following formula: Reduction $(\%)=(\mathrm{AB} / \mathrm{BC}) \times 100$, where $A$ is the average number of cells with $\mathrm{MN}$ observed with the damage inducing agent $\left[{ }^{131} \mathrm{I}\right], B$ is the number of cells with $\mathrm{MN}$ observed with the radioprotective treatment (simultaneous treatment $\left[{ }^{131} \mathrm{I}\right]+$ acerola or beta-carotene), and $C$ is the number of cells with $\mathrm{MN}$ in the negative control test.

Statistical analysis was carried out using ANOVA and the Tukey test $(\alpha=0.05)$.

\section{Obtaining extracts of acerola for physico-chemical analysis}

The acerolas were washed with running potable water, and the edible part, pulp, and rind were separated manually. The pulp was disintegrated manually, prepared, and frozen in a household refrigerator, protected from light until further analysis.

Treatments were prepared with three different extracts of acerola pulp and were performed with the addition of dilution water. The methanol extract $50 \% / 70 \%$ acetone was prepared according to the methodology described by Rufino et al. (2007). Besides these extracts, aqueous extracts ( $80 \%$ methanol and $80 \%$ acetone) were prepared using the solvent extractor with $2.0 \mathrm{~g}$ pulp agitation in the dark for $60 \mathrm{~min}$. The extracts were not lyophilized.

\section{Determination of total phenols}

The total phenols of the four extracts were determined using the Folin-Ciocalteu reagent and a standard curve of gallic acid as a reference according to the methodology described by Wettasinghe and Shahidi (1999). The total phenol content was expressed as mg gallic acid/100 g pulp. The statistical calculation was performed using the Tukey test $(\mathrm{N}=3 ; \alpha=0.05)$.

\section{Determination of antioxidant activity by DPPH scavenging}

The free radical scavenging activity of four extracts obtained from acerola pulp was determined using the method using 1,1-diphenyl-2-picrylhydrazyl (DPPH) and a series of dilutions, as described by Brand-Williams et al. (1995) and modified by Miliauskas et al. (2004). The absorbance was read at $515 \mathrm{~nm}$ after the reaction of extract and DPPH solution had been incubated at room temperature for $30 \mathrm{~min}$.

BHT (2,6-di-terc-butyl-4-methylphenol) was used as a reference substance for free radical scavenging activity (positive control). Antioxidant activity (AA), expressed as a percentage, was calculated in relation to the control according to the expression below:

$$
\mathrm{AA} \%=(\text { Acontrol }- \text { Asample }) \times 100 /(\text { Acontrol })
$$

The extract concentration required for $50 \%$ capture of free radical DPPH $\left(\mathrm{IC}_{50}\right)$ was calculated by linear regression. The statistical calculation was performed using the Tukey test $(\mathrm{N}=3 ; \alpha=0.05)$. 


\section{Determination of ascorbic acid levels}

For the determination of ascorbic acid content, the methodology described by Horwitz (2000) and modified by Benassi and Antunes (1998) was used. Briefly, pulp solution was extracted with $2 \%$ oxalic acid and titration with $0.01 \%$ 2,6-dichlorophenolindophenol to obtain a clear pink color. The results were expressed as $\mathrm{mg}$ ascorbic acid/100 $\mathrm{g}$ sample.

\section{Determination of total carotenoids}

The determination of total carotenoids was performed according to the methodology described by Higby (1962) in which the acerola pulp was extracted with isopropyl alcohol:hexane (3:1). The absorbance was read at $450 \mathrm{~nm}$, and the results were expressed as $\mathrm{mg} / 100 \mathrm{~g}$ pulp, as calculated using the following formula:

Total carotenoids $=\left(\mathrm{A}_{450} \times 100\right) /(250 \times \mathrm{L} \times \mathrm{W})$,

where: $A=$ absorbance, $L=$ cuvette width in $\mathrm{cm}, W=$ quotient between the mass of the original sample in $\mathrm{g}$ and the final volume of dilution in $\mathrm{mL}$.

\section{Determination of total anthocyanins and yellow flavonoids}

The determination of total anthocyanins followed the method of Francis (1982). The extracting solution used was $95 \%$ ethanol $+1.5 \mathrm{~N} \mathrm{HCl}(85: 15)$ proceeding reading the absorbance at $535 \mathrm{~nm}$ for anthocyanins and $374 \mathrm{~nm}$ for yellow flavonoids. The results were expressed as $\mathrm{mg} / 100 \mathrm{~g}$ pulp, as calculated using the formulas:

Total anthocyanins $=$ dilution factor $\mathrm{x}$ absorbance $/ 98.2$

Yellow flavonoids $=$ dilution factor $\mathrm{x}$ absorbance $/ 76.6$

\section{RESULTS}

The average number of MN (Figure 1) indicates that only the highest dose of $\left[{ }^{131} \mathrm{I}\right]$ tested $(10 \mu \mathrm{Ci})$ resulted in significantly different data compared to the negative control $(\mathrm{P}<$ $0.001)$; in contrast, the lower doses tested $(0.1,0.5,1$, and $5 \mu \mathrm{Ci})$ were not significantly different from the negative control. Moreover, the different concentrations of $\left[{ }^{131} \mathrm{I}\right]$ had a statistically similar average number of MN according to the Tukey test.

The NDI of the groups that were treated with $\left[{ }^{131} \mathrm{I}\right]$ (Table 1) indicates that radioiodine (at any dose) was not significantly different from the negative control. However, all of the concentrations tested caused an increase in the NDI.

Results indicate that synthetic beta-carotene and acerola fruit pulp were not mutagenic; the average number of MN was similar to the negative control, as shown in Figure 2. Furthermore, neither of the treatments was cytotoxic, and the NDI data were similar to the negative control (Table 2).

The results of the radiation protection test showed that simultaneous treatment with acerola and $\left[{ }^{131} \mathrm{I}\right]$ was statistically similar to the negative control, similar to treatment with only 
acerola and with only $\left.{ }^{131} \mathrm{I}\right](10 \mu \mathrm{Ci})$ (Figure 3). When beta-carotene was administered with the radioisotope, the average number of $\mathrm{MN}$ was significantly different than the negative control $(\mathrm{P}<$ $0.01)$, the treatment with DMSO $(\mathrm{P}<0.05)$, and the treatment that included only beta-carotene $(0.2$ $\mu \mathrm{M})(\mathrm{P}<0.001)$; however, these data were similar to treatment with only $\left[{ }^{131} \mathrm{I}\right](10 \mu \mathrm{Ci})$ (Figure 3$)$.

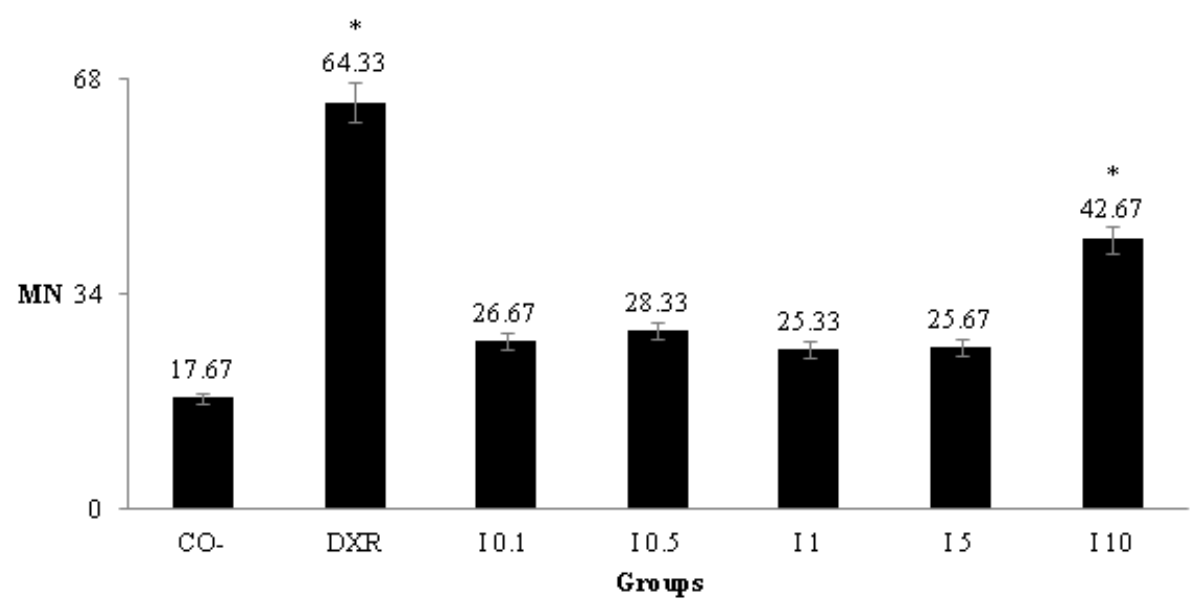

Figure 1. Average number of micronuclei (MN) and standard deviation for the negative (CO-) and positive (DXRdoxorubicin) control groups compared to the groups exposed to 0.1 to $10 \mu \mathrm{Ci}$ of $\left[{ }^{131} \mathrm{I}\right]$. ${ }^{*}$ The results are significantly different compared to the CO-.

Table 1. Mean nuclear division index (NDI) and standard deviation of 1500 control cells compared to cells that were exposed to five concentrations of $\left[{ }^{131} \mathrm{I}\right](\mu \mathrm{Ci})$.

\begin{tabular}{lcc}
\hline Group & Total cells analyzed & NDI (means \pm SD) \\
\hline CO- & 1500 & $1.46 \pm 0.07$ \\
DXR & 1500 & $1.43 \pm 0.12$ \\
Iodine 0.1 & 1500 & $1.70 \pm 0.13$ \\
Iodine 0.5 & 1500 & $1.67 \pm 0.10$ \\
Iodine 1 & 1500 & $1.57 \pm 0.12$ \\
Iodine 5 & 1500 & $1.63 \pm 0.01$ \\
Iodine 10 & 1500 & $1.65 \pm 0.02$ \\
\hline
\end{tabular}

CO- = negative control; DXR = doxorubicin.

As is shown in Table 3, simultaneous treatment with beta-carotene or acerola with ${ }^{\left[{ }^{131} \mathrm{I}\right]}$ significantly decreased the NDI $(\mathrm{P}<0.001$ for beta-carotene and $\mathrm{P}<0.05$ for acerola $)$ compared to $\left[{ }^{131} \mathrm{I}\right]$ exposure. Furthermore, treatment with beta-carotene plus $\left[{ }^{131} \mathrm{I}\right]$ resulted in lower NDI values than that observed for the beta-carotene only treatment.

The results of physic-chemical analysis show that acerola pulp is as excellent antioxidant (Table 4), with $\mathrm{IC}_{50}$ values to $50 \%$ methanol $/ 70 \%$ acetone, water and $80 \%$ methanol extracts about 257.1 to $290.33 \mu \mathrm{g} / \mathrm{mL}$. In addition, acerola pulp was found to contain high levels of antioxidant compounds (ascorbic acid, anthocyanins, carotenoids, total phenols, and yellow flavonoids) (laboratory data published in Düsman et al., 2012a). 


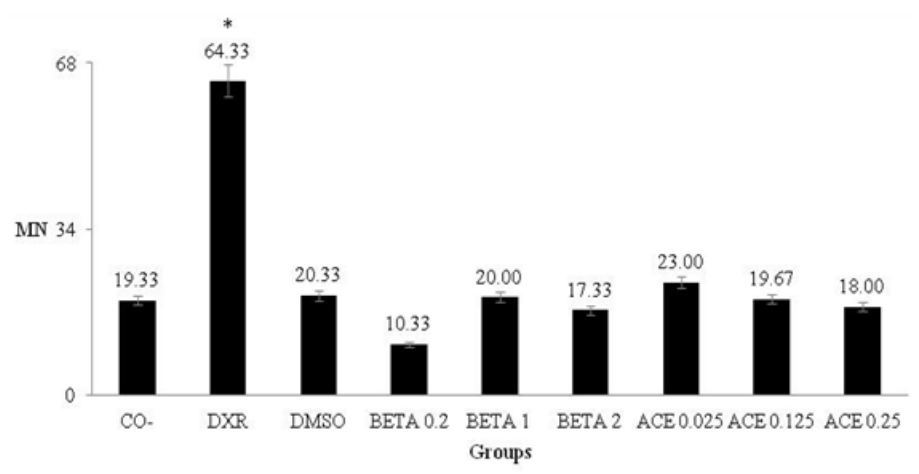

Figure 2. Average number of micronuclei $(\mathrm{MN})$ and standard deviation for the negative (CO-) and positive (DXRdoxorubicin) control groups compared to groups treated with $10 \mu \mathrm{L}$ of $\mathrm{DMSO} / \mathrm{mL}$ (dimethylsulfoxide), $0.2,1$, and $2 \mu \mathrm{M}$ of beta-carotene (BETA) and $0.025,0.125$ and $0.25 \mathrm{~g}$ of acerola pulp/mL (ACE). *The results are significantly different from the CO-.

Table 2. Mean nuclear division index (NDI) and standard deviation of 1500 control cells compared to cells that were treated with three concentrations of beta-carotene $(\mu \mathrm{M})$ and acerola $(\mathrm{g} / \mathrm{mL})$.

\begin{tabular}{lcc}
\hline Group & Total cells analyzed & NDI (means \pm SD) \\
\hline CO- & 1500 & $1.50 \pm 0.05$ \\
DXR & 1500 & $1.43 \pm 0.12$ \\
DMSO & 1500 & $1.38 \pm 0.01$ \\
BETA 0.2 & 1500 & $1.57 \pm 0.07$ \\
BETA 1 & 1500 & $1.55 \pm 0.04$ \\
BETA 2 & 1500 & $1.42 \pm 0.03$ \\
ACE 0.025 & 1500 & $1.37 \pm 0.04$ \\
ACE 0.125 & 1500 & $1.68 \pm 0.10$ \\
ACE 0.25 & 1500 & $1.67 \pm 0.10$ \\
\hline
\end{tabular}

$\mathrm{CO}-=$ negative control; $\mathrm{DXR}=$ doxorubicin; $\mathrm{DMSO}=$ dimethylsulfoxide; $\mathrm{BETA}=$ beta-carotene; $\mathrm{ACE}=$ acerola.

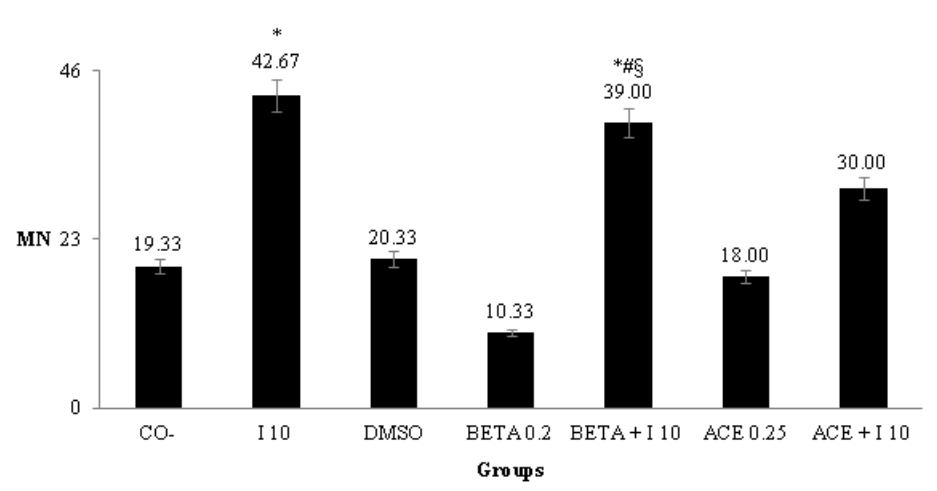

Figure 3. Average number of micronuclei (MN) and standard deviation for the negative control group (CO-) and groups treated with $10 \mu \mathrm{Ci}$ of ${ }^{131}$ Iodine (I), $10 \mu \mathrm{L}$ of $\mathrm{DMSO} / \mathrm{mL}$ (dimethylsulfoxide), $0.2 \mu \mathrm{M}$ of beta-carotene (BETA), and $0.25 \mathrm{~g}$ of acerola pulp/mL (ACE), with and without $\left[{ }^{131} \mathrm{I}\right]$. *The results are significantly different compared to the negative control (CO-). \#The results are significantly different compared to DMSO. §The results are significantly different compared to beta-carotene. 
Table 3. Mean nuclear division index (NDI) and standard deviation of 1500 control cells compared to cells that were treated with beta-carotene $(\mu \mathrm{M})$ or acerola $(\mathrm{g} / \mathrm{mL})$ and $\left[{ }^{131} \mathrm{I}\right](\mu \mathrm{Ci})$.

\begin{tabular}{lcc}
\hline Group & Total cells analyzed & NDI (means \pm SD) \\
\hline CO- & 1500 & $1.50 \pm 0.05$ \\
Iodine 10 & 1500 & $1.65 \pm 0.02$ \\
DMSO & 1500 & $1.38 \pm 0.01$ \\
BETA 0.2 & 1500 & $1.57 \pm 0.07$ \\
BETA + I 10 & 1500 & $1.30 \pm 0.04^{*} \#$ \\
ACE 0.25 & 1500 & $1.68 \pm 0.10$ \\
ACE + I 10 & 1500 & $1.43 \pm 0.13^{*}$ \\
\hline
\end{tabular}

CO- = negative control; DMSO = dimethylsulfoxide; $\mathrm{BETA}$ = beta-carotene; I = iodine; ACE = acerola. $*$ The results are significantly different compared to Iodine 10 . \#The results are significantly different compared to BETA 0.2.

Table 4. Total phenols values and antioxidant activity expressed in $\mathrm{IC}_{50}$, concentration in $\mu \mathrm{g} / \mathrm{mL}$ needed to capture $50 \%$ of the free radical DPPH.

\begin{tabular}{lcc}
\hline Extracts & Total phenols (mg gallic acid $/ 100 \mathrm{~g}$ of pulp) & $\mathrm{IC}_{50}$ \\
\hline Methanol $50 \% /$ acetone $70 \%$ & $4478.37 \pm 361.36^{\mathrm{a}}$ & $260.58 \pm 8.76^{\mathrm{bc}}$ \\
Water & $4631.70 \pm 55.00^{\mathrm{a}}$ & $257.10 \pm 6.89^{\mathrm{bc}}$ \\
Methanol $80 \%$ & $6142.65 \pm 15.80$ & $290.33 \pm 27.48^{\mathrm{bc}}$ \\
Acetone $80 \%$ & $4807.84 \pm 102.58^{\mathrm{a}}$ & $579.92 \pm 43.80^{\mathrm{c}}$ \\
BHT $2500 \mu \mathrm{g} / \mathrm{mL}$ & - & $24.47 \pm 1.81$ \\
\hline
\end{tabular}

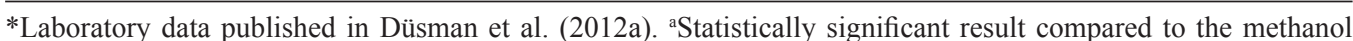
extract $80 \%(\mathrm{P}<0.05)$. ${ }^{b}$ Statistically significant result compared to the acetone extract $80 \%(\mathrm{P}<0.001)$. ${ }^{\text {cStatistically }}$ significant result compared to the BHT $(\mathrm{P}<0.001)$.

\section{DISCUSSION}

The results showed that only the highest dose of $\left[{ }^{131} \mathrm{I}\right]$ tested $(10 \mu \mathrm{Ci})$ was mutagenic, but it is noteworthy that all of the radioisotope doses resulted in a greater number of MN than the negative control. These data indicate a dose-dependent action, because the increased concentration of radiation was an increased frequency of MN. Dose-dependent results were also found by Gutiérrez et al. (1997), as patients that received low doses of $\left[{ }^{131} \mathrm{I}\right](\leq 13,513.51$ $\mu \mathrm{Ci}$ ), did not have frequencies of MN and binucleated cells with $\mathrm{MN}$ that were significantly different than those obtained before treatment. However, in patients receiving doses greater than $13,513.51 \mu \mathrm{Ci}\left[{ }^{131} \mathrm{I}\right]$, there was an increase in the frequency of $\mathrm{MN}$ and binucleated cells with $\mathrm{MN}$, which was similar to what we observed for doses of $10 \mu \mathrm{Ci}$.

$\mathrm{MN}$, which is a small nuclear mass that is surrounded by membrane and separated from the main nucleus, can be derived from chromatid or chromosome breaks (Fenech, 2000); although Saffi and Henriques (2003) argue that chromatid/chromosome breaks are the main type of radiation-induced DNA damage, MN may also result from single-strand breaks, double-strand breaks, base and sugar damage, and oxidative damage to bases between proteinDNA and DNA-DNA interchange bridges.

Federico et al. (2008) reported negative results for the MN test using blood from 11 patients who received an average of $94,594.59 \pm 10,000 \mu \mathrm{Ci}\left[{ }^{131} \mathrm{I}\right]$ for ablation of thyroidal remnants. According to the authors, this may be due to an early activation of cellular repair machinery that maintains the integrity of the genome and may prevent double-strand DNA 
breaks from progressing to chromosomal mutations by either repairing the lesions or by eliminating the damaged cells via apoptosis. It is possible that these mechanisms may also have occurred in our HTC cells that were treated with $0.1,0.5,1$, and $5 \mu \mathrm{Ci}\left[{ }^{131} \mathrm{I}\right]$, as these doses of radioisotope appeared less mutagenic than the highest dose of $10 \mu \mathrm{Ci}$.

It is possible that an induction of these cellular defense mechanisms may have altered cell division; however, the nuclear division indexes (Table 1) indicate no cytotoxic effect toward the HTC cells. Similar results were previously reported by da Silva et al. (2008), where treatment with $100,000 \mu \mathrm{Ci}\left[{ }^{131} \mathrm{I}\right]$ did not alter the cell proliferation kinetics of blood lymphocytes in Wistar rats.

Our data suggest that high concentrations of $\left[{ }^{131} \mathrm{I}\right](10 \mu \mathrm{Ci})$ are mutagenic toward $R$. norvegicus HTC cultured, which agrees with previously published data from Watanabe et al. (2004) and Joseph et al. (2009); these studies also used the MN test to assess DNA damage and showed that there was significant DNA damage in human peripheral lymphocytes at the doses 100,000 and 10,000 to $850,000 \mu \mathrm{Ci}\left[{ }^{131} \mathrm{I}\right]$, respectively. These data indicate that higher doses cause greater damage to cells and have a dose-dependent effect, as indicated by Gutiérrez et al. (1997). Additional studies also reported an increased frequency of chromosomal alterations in lymphocyte cells (da Silva et al., 2008) and bone marrow of Wistar rats treated with different doses of $\left[{ }^{131} \mathrm{I}\right]$ (Düsman et al., 2011).

It is noteworthy that although the highest concentration of $\left.{ }^{131} \mathrm{I}\right]$ may have been mutagenic, it was not significantly different from the other doses tested, which induced more $\mathrm{MN}$ compared to the negative control. Moreover, concentrations of $\left[{ }^{131} \mathrm{I}\right]$ from 0.1 to $5 \mu \mathrm{Ci}$ had a statistically similar average number of $\mathrm{MN}$, similar to the results previously described by Düsman et al. (2011) in which different doses of $\left[{ }^{131} \mathrm{I}\right]$ resulted in a similar percentage of induced chromosomal aberrations in the bone marrow of Wistar rats.

The results of this study indicate that neither the antioxidants tested (synthetic betacarotene and acerola fruit pulp) was mutagenic or cytotoxic. It has been shown previously that beta-carotene was not mutagenic toward the bone marrow cells of mice and rats based on the MN test (El-Habit et al., 2000; El-Makawy and El-Ashmaoui, 2003) and was not toxic (2.5, 3.75 , and $5.0 \mathrm{mg}$ ) when administered to rats (Oliveira et al., 2007). The data from Düsman et al. (2012b) corroborate these results because, in natura, acerola pulp $(0.2,0.4$ and $5.0 \mathrm{mg} / \mathrm{mL})$ and, frozen pulp $(0.2$ and $0.4 \mathrm{mg} / \mathrm{mL})$ also showed no mutagenic and cytotoxic activity in bone marrow cells of Wistar rats based on the chromosomal aberration test. In addition, using the comet assay, Nunes et al. (2011) also showed that $0.5,1$, and $2 \mathrm{mg} / \mathrm{mL}$ unripe and ripe acerola fruit showed no genotoxicity in rat cells.

Because beta-carotene $(0.2 \mu \mathrm{M})$ and acerola pulp $(0.25 \mathrm{~g} / \mathrm{mL})$ do not exert cytotoxic or mutagenic effects, and because we observed a lower number of $\mathrm{MN}$ among the concentrations tested, we evaluated the radioprotective activity of these compounds in response to exposure to a high dose of $\left[{ }^{131} \mathrm{I}\right](10 \mu \mathrm{Ci})$.

The results showed that treatment with acerola plus $\left[{ }^{131} \mathrm{I}\right]$ was not mutagenic, and although the data are not significantly different from treatment with only $\left[{ }^{131} \mathrm{I}\right]$, the simultaneous treatment with acerola decreased the average number of $\mathrm{MN}$ induced by the radioisotope by greater than 50\% (Figure 3). Nunes et al. (2011) previously showed that unripe acerola fruit demonstrates greater DNA damage protection against hydrogen peroxide damage compared to ripe fruit extracts. Thus, unripe acerola fruit may exert more significant radioprotection compared to the fresh pulp that was tested here. 
It is possible that administration of acerola pulp decreased the number of $\mathrm{MN}$ that were induced by $\left[{ }^{131} \mathrm{I}\right]$ ionizing radiation, as indicated by Wakabayashi et al. (2003) and Hanamura et al. (2005), because certain acerola components (i.e., anthocyanins) can scavenge free radicals. The results of physico-chemical analysis corroborate the beneficial radioprotective effect of acerola in the present study, as we showed that acerola pulp had high levels of antioxidant potential $\left(\mathrm{IC}_{50}\right.$ about 257.1 to $290.33 \mu \mathrm{g} / \mathrm{mL}$ by $50 \%$ methanol $/ 70 \%$ acetone, water and $80 \%$ methanol extracts) (Table 4) and antioxidant compounds, similar to ascorbic acid (1960.02 $\pm 2.32 \mathrm{mg} / 100$ g sample), anthocyanins $(8.09 \pm 0.09 \mathrm{mg} / 100 \mathrm{~g}$ sample $)$, carotenoids $(0.615 \pm 0.005 \mathrm{mg} / 100 \mathrm{~g}$ sample), yellow flavonoids ( $11.03 \pm 0.13 \mathrm{mg} / 100 \mathrm{~g}$ sample), and total phenols (6142.65 \pm 15.80 mg gallic acid/100 g pulp) (Table 4) (laboratory data published in Düsman et al., 2012a).

Nunes et al. (2011) also claim that the protective effect exerted by acerola may be related to vitamin $\mathrm{C}$ and the complex mixture of nutrients, especially in the unripe fruit. This mixture of nutrients may interact with the DNA and protect it from oxidative stress. In this sense, Blumenthal et al. (2000) also reported that the combination of vitamins E, C, and A, when administered to mice for 14 days ( 3 days before and 11 days after radiation exposure), reduced the toxic effect of radioimmunotherapy with $400 \mu \mathrm{Ci}\left[{ }^{131} \mathrm{I}\right]$.

According to Calegaro (2007), the human body can respond to ionizing radiation by neutralizing oxidizing radicals, repairing structural changes that have occurred in the DNA, inducing apoptosis if there are signs of cell instability, activating immune responses, and by recognizing the damaged cell as foreign by changes in the membrane. All of these mechanisms may have been stimulated during simultaneous treatment with acerola and $\left[{ }^{131} \mathrm{I}\right]$, which resulted in a lower number of $\mathrm{MN}$.

Aside from this, significant decreases in NDI after simultaneous treatment with acerola or beta-carotene (Table 3) could be explained by the fact high NDI observed after treatment with $10 \mu \mathrm{Ci}\left[{ }^{131} \mathrm{I}\right]$ may have resulted from the cells attempt to rapidly divide in response to damage and quickly replace the damaged cells, as was previously described by Düsman et al. (2011). Thus, acerola and beta-carotene, when administered with $\left[{ }^{131} \mathrm{I}\right]$, may have reduced cell damage and decreased the NDI.

However, beta-carotene had no effect on the mutagenic activity of $\left[{ }^{131} \mathrm{I}\right]$ in this study and only decreased the number of MN by approximately $16 \%$ (Figure 3). Furthermore, treatment with beta-carotene plus $\left[{ }^{131} \mathrm{I}\right]$ resulted in a lower NDI than that observed after treatment with beta-carotene only, in agreement with data previously published by Morales-Ramirez et al. (1998) in which the authors observed a synergistic effect of beta-carotene and gamma radiation. Treatment with radiation and the carotenoid appeared to increase the frequency of sister chromatid exchanges induced by gamma radiation in mice bone marrow cells that were treated before and after irradiation.

Although beta-carotene is an antioxidant, previous studies have suggested that it also has pro-oxidant and pro-carcinogenic activity (Young and Lowe, 2001; Lowe et al., 2003) because antioxidant activity depends on the pigment concentration and oxygen tension in the tissue. At high concentrations, this carotenoid may have antagonistic activity (i.e., prooxidant) and may induce oxidative stress by increasing free radicals or by failing to decrease the mutagenicity of $\left[{ }^{131} \mathrm{I}\right]$ ionizing radiation.

Thus, the consumption of vegetables that contain several antioxidants, such as acerola fruit, which contains vitamin C, carotenoids, anthocyanins, yellow flavonoids, and phenols, may be more beneficial than consumption of individual synthetic carotenoids like beta-car- 
otene. Because there are numerous adverse side effects that are associated with radioiodine exposure, and because fresh acerola pulp appears to protect against radiation DNA damage. Future studies should be conducted to determine if acerola consumption can alleviate the harmful side effects of human $\left[{ }^{131} \mathrm{I}\right]$ exposure as a result of thyroid diagnostics and therapy.

\section{ACKNOWLEDGMENTS}

The authors thank Fundação Araucária for financing the research through the approval of a project to purchase materials and equipment.

\section{REFERENCES}

Almeida IV, Heck MC, Pedroso GA and Vicentini VEP (2011). Evaluation of Mutagenic Activity of Flunitrazepam in HTC Cell Lines Using the Micronucleus Test. Anais of X Congresso Brasileiro SBMCTA, São Pedro.

Ben-Amotz A, Yatziv S, Sela M, Greenberg S, et al. (1998). Effect of natural $\beta$-carotene supplementation in children exposed to radiation from the Chernobyl accident. Radiat. Environ. Biophys. 37: 187-193.

Benassi MT and Antunes AJ (1998). A comparison of metaphosphoric and oxalic acids as extractants solutions for the determination of vitamin C in selected vegetables. Arq. Biol. Tecnol. 31: 507-513.

Blumenthal RD, Lew W, Reising A, Soyne D, et al. (2000). Anti-oxidant vitamins reduce normal tissue toxicity induced by radio-immunotherapy. Int. J. Cancer 86: 276-280.

Brand-Williams W, Cuvelier ME and Berset C (1995). Use of a free radical method to evaluate antioxidant activity. LWT - Food Sci. Technol. 28: 25-30.

Calegaro JUM (2007). Baixos níveis de radiação ionizante causam câncer? Radiol. Bras. 40: 9-10.

da Silva MA, Calil Cury Guimaraes MI, Yoriyaz H, Carvalho Pinto Ribela MT, et al. (2008). Evaluation of the cytogenetic effects of ${ }^{131} \mathrm{I}$ preceded by recombinant human thyrotropin $(\mathrm{rhTSH})$ in peripheral lymphocytes of Wistar rats. Radiat. Environ. Biophys. 47: 453-461.

De Flora S and Ferguson LR (2005). Overview of mechanisms of cancer chemopreventive agents. Mutat. Res. 591: 8-15.

Düsman E, Berti AP, Mariucci RG, Lopes NB, et al. (2011). Mutagenicity of diagnostic and therapeutical doses of radiopharmaceutical iodine-131 in Wistar rats. Radiat. Environ. Biophys. 50: 579-584.

Düsman E, Berti AP, Mariucci RG and Lopes NB (2012a). Radioprotective effect of the Barbados cherry (Malpighia glabra L.) against radiopharmaceutical iodine-131 in wistar rats in vivo. BMC Complement. Altern. Med. (in press).

Düsman E, Ferreira MFS, Berti AP, Mariucci RG, et al. (2012b). Investigation of cytotoxic and mutagenic effects of Malpighia glabra L. (barbados cherry) fruit pulp and vitamin C on plant and animal test systems. Cienc. Tecnol. Aliment. 32: 405-411.

El-Habit OH, Saada HN, Azab KS, Abdel-Rahman M, et al. (2000). The modifying effect of $\beta$-carotene on gamma radiation-induced elevation of oxidative reactions and genotoxicity in male rats. Mutat. Res. 466: 179-186.

El-Makawy A and El-Ashmaoui HM (2003). Evaluation of the protective activity of beta-carotene and 1-carnitine on doxorubicin -induced genotoxicity in rats. Arab. J. Biotechnol. 6: 289-296.

Federico G, Boni G, Fabiani B, Fiore L, et al. (2008). No evidence of chromosome damage in children and adolescents with differentiated thyroid carcinoma after receiving ${ }^{131}$ I radiometabolic therapy, as evaluated by micronucleus assay and microarray analysis. Eur. J. Nucl. Med. Mol. Imaging 35: 2113-2121.

Fenech M (2000). The in vitro micronucleus technique. Mutat. Res. 455: 81-95.

Francis FJ (1982). Analysis of Anthocyanins. In: Anthocyanins as Food Colors (Markakis P, ed.). Academic Press, New York, 181-207.

Gutiérrez S, Carbonell E, Galofre P, Creus A, et al. (1997). Micronuclei induction by ${ }^{131}$ I exposure: study in hyperthyroidism patients. Mutat. Res. 373: 39-45.

Hanamura T, Hagiwara T and Kawagishi H (2005). Structural and functional characterization of polyphenols isolated from acerola (Malpighia emarginata DC.) fruit. Biosci. Biotechnol. Biochem. 69: 280-286.

Higby WK (1962). A simplified method for determination of some the carotenoid distribution in natura and carotene fortified orange juice. J. Food Sci. 27: 42-49.

Horwitz W (2000). Official Methods of Analysis of the Association of Official Analytical Chemists. 17th edn. AOAC, Gaithersburg.

Hosseinimehr SJ (2007). Trends in the development of radioprotective agents. Drug Discov. Today 12: 794-805.

Genetics and Molecular Research 12 (4): 6402-6413 (2013)

CFUNPEC-RP www.funpecrp.com.br 
Joseph LJ, Bhartiya US, Raut YS, Kand P, et al. (2009). Micronuclei frequency in peripheral blood lymphocytes of thyroid cancer patients after radioiodine therapy and its relationship with metastasis. Mutat. Res. 675: 35-40.

Loureiro APM, Di Mascio P and Medeiros MHG (2002). Formação de adutos exocíclicos com bases de DNA: implicações em mutagênese e carcinogênese. Química Nova 25: 777-793.

Lowe GM, Vlismas K and Young AJ (2003). Carotenoids as prooxidants? Mol. Aspects Med. 24: 363-369.

Marques LG, Ferreira MC and Freire JT (2007). Freeze-drying of acerola (Malpighia glabra L.). Chem. Eng. Process. 46: 451-457.

Martins de Oliveira J, Jordao BQ, Ribeiro LR, Ferreira da EA, et al. (2002). Anti-genotoxic effect of aqueous extracts of sun mushroom (Agaricus blazei Murill lineage 99/26) in mammalian cells in vitro. Food Chem. Toxicol. 40: 17751780.

Mezadri T, Fernandez-Pachon MS, Villano D, Garcia-Parrilla MC, et al. (2006). The acerola fruit: composition, productive characteristics and economic importance. Arch. Latinoam. Nutr. 56: 101-109.

Miliauskas G, Venskutonis PR and van Beek TA (2004). Screening of radical scavenging activity of some medicinal and aromatic plant extracts. Food Chem. 85: 231-237.

Morales-Ramirez P, Mendiola-Cruz MT and Cruz-Vallejo V (1998). Effect of vitamin C or beta-carotene on SCE induction by gamma rays in radiosensitized murine bone marrow cells in vivo. Mutagenenis 2: 139-144.

Nunes RS, Kahl VF, Sarmento MS, Richter MF, et al. (2011). Antigenotoxicity and antioxidant activity of acerola fruit (Malpighia glabra L.) at two stages of ripeness. Plant Foods Hum. Nutr. 66: 129-135.

Oliveira GS, Figueiredo ASP, Santos RS and Vianna LM (2007). Efeito da suplementação de beta-caroteno na pressão arterial de ratos. Rev. Nutr. 20: 39-45.

Puerto S, Marcos R, Ramirez MJ, Galofre P, et al. (2000). Equal induction and persistence of chromosome aberrations involving chromosomes 1,4 , and 10 in thyroid cancer patients treated with radioactive iodine. Mutat. Res. 469: 147-158.

Ratnam DV, Ankola DD, Bhardwaj V, Sahana DK, et al. (2006). Role of antioxidants in prophylaxis and therapy: A pharmaceutical perspective. J. Control. Release 113: 189-207.

Rufino MSM, Alves RE, Brito ES, Morais SM, et al (2007). Metodologia Científica: Determinação da Atividade Antioxidante Total em Frutas pela Captura do Radical Livre DPPH. Comunicado Técnico, Embrapa, Fortaleza.

Saffi J and Henriques JAP (2003). Reparação de DNA em Células Eucarióticas. In: Genética Toxicológica (Silva J, Erdtman B and Henriques JAP, eds.). Alcance, Porto Alegre.

Thrall JH and Ziessman HA (2003). Medicina Nuclear. 2nd edn. Guanabara Koogan, Rio de Janeiro.

Turgut B, Ozdemir O and Erselcan T (2006). Evaluation of the p53 tumor suppressor gene mutation in normal rat salivary gland tissue after radioiodine application: an experimental study. Adv. Ther. 23: 456-468.

Wakabayashi H, Fukushima H, Yamada T, Kawase M, et al. (2003). Inhibition of LPS-stimulated NO production in mouse macrophage-like cells by Barbados cherry, a fruit of Malpighia emarginata DC. Anticancer Res. 23: 3237-3241.

Watanabe N, Kanegane H, Kinuya S, Shuke N, et al. (2004). The radiotoxicity of ${ }^{131}$ I therapy of thyroid cancer: assessment by micronucleus assay of B lymphocytes. J. Nucl. Med. 45: 608-611.

Wettasinghe M and Shahidi F (1999). Evening primrose meal: a source of natural antioxidants and scavenger of hydrogen peroxide and oxygen-derived free radicals. J. Agric. Food Chem. 47: 1801-1812.

Young AJ and Lowe GM (2001). Antioxidant and prooxidant properties of carotenoids. Arch. Biochem. Biophys. 385 : 20-27. 